\title{
Diakonia in the Public Sphere - a Daughter of the Church, or its Sister?
}

\section{Church and Diakonia Between Separation and Approximation Karel Šimr}

Throughout the ecumenical spectrum, the issue of the relationship of the church and diakonia has mostly been answered within the pastoral-theological theory of the church's constitutive features. Within that theory, diakonia is, together with martyria and leitourgia (and possibly koinonia) understood as one of the elements through which the church realises itself. ${ }^{1}$ But if in this paper the term diakonia is used to signify the empirical reality of the present forms of social work operated by the churches in the public sphere within the structures of the social state, then the question arises of whether that theory makes it possible to capture that practice in a sufficient manner. Acknowledging that does not cast any doubt on the significance of the 'general diaconate' of the faithful, or on the effort to renew the basic diaconic self-awareness of the church as a local Christian community. Despite all justified searching for the diaconic church, there remains the challenge of adequately theoretically capturing the dominant form of contemporary diaconic work of the churches, as it has evolved in history, in its incongruousness and, based on that, determine its relationship to the church and to society. In my reasoning, I want to attempt that in three steps - by historical reminiscence, by sociological analysis, and by theological evaluation.

\section{The problem of dual adherence}

First, I will attempt to show in several examples from the Protestant milieu (also because that is where the beginnings of the contemporary form of organised diaconic and charitable work are to be sought in the mid-19 $9^{\text {th }}$ century) that in modern society diakonia in fact arose outside the institutionalised church.

Let us begin with a glimpse into the Reformation, which has greatly contributed to the shift in responsibility for the social sphere to the secular authorities (the Lutheran Reformation tended towards that strongly; the Reformed branch attempted to bind the responsibility for social issues more to the congregation, for example, with the effort to renew the diaconate as part of the fourfold office of the church, but even there applying the principle of delegating the diaconic tasks to the magistrates eventually prevailed). This tension can be clearly observed in the reform efforts of Martin Bucer in Strasbourg. When in 1523 he began his reform activity there, all social responsibility was already carried by the town administration and a congregational diaconate thus appeared to be superfluous. For Bucer, for whom the church existed both in the form of

1 See, for example, Markus Lehner, Prokrustovo lože - systematizace pastorálky, in: Teologické texty 5/1996, p. 149. 
a confessing community and in the form of a Christian society, it was important to ground social help at both these levels. That is why he strove to incorporate the representatives of municipal social care also in the church structure and to establish them as deacons according to the biblical understanding. ${ }^{2}$ But Bucer's attempt to ground diaconic work both in the institutional church and in the secular structures of society did not succeed. Later, the already indicated problem of the dual perspective of the organised work of help became even more acute, because both for the religious sphere and for the state it is difficult to admit a dual loyalty of action. ${ }^{3}$ This finding does not express a criticism of the new forms of social help in society; it merely raises the question or challenge of the diaconic responsibility of the church.

While the Reformation constitutes the pre-history of the contemporary situation of diakonia in the public sphere, the particular beginnings of its present form are linked to the work of the German theologian and founder of the so-called Inner Mission Johann Hinrich Wichern in Germany in the mid- $19^{\text {th }}$ century. In his time, Wichern was reacting to the social consequences of the Industrial Revolution. He aimed to give a Christian answer to the social and spiritual poverty of the population. His real goal was an inner mission of the German nation, i.e., its overall re-Christianisation, an inseparable part of which was social help. But even in this case it is not possible to speak of an ecclesial diaconic work in the strict sense of the word. Wichern based the Inner Mission not within the institutional church, but in free associational life. He distinguished this civic diakonia - in the spirit of the Lutheran doctrine of the two regimens - from ecclesial diakonia, which in his view ought to consist primarily in renewing the congregational diaconate. However, the development not only in Germany and not only in the Protestant milieu rather took the path of developing diakonia in the public sphere. This trend was further reinforced with the development of the social state after World War II. In Germany, diaconic work was first tied to the institutional church by force during the Nazi era. After the war, the newly arisen official church-operated Evangelical Work of Help and the free Inner Mission continued to work side by side and in 1957 they were merged. But the process of fusion culminated only in 1975 with the establishment of the Diaconic Work of the Evangelical Church in Germany. ${ }^{4}$

A similar development can also be observed in the Czech context within Diaconia of the Evangelical Church of Czech Brethren. It was established as a result of the liberalisation of the political situation in the months shortly before the coup in 1989 by an initiative of the then synod curator Miloš Lešikar without a deeper grounding in the church. Although there has always also been an awareness that the two institutions belong together, the first years of the organisation's development testify rather to the efforts to gain greater autonomy from the church, which the management perceived as a factor necessary for developing the work in society. A certain change in the direction of the trend is evinced at the turn of the millennium by the words of Zdeněk Bárta that 'the ten-year-long gradual incorporation of Diaconia into the body of the church and the

2 Gerhard K. Schäfer and Volker Hermann, Geschichtliche Entwicklungen der Diakonie von der Alten Kirche bis zur Gegenwart im Überblick, in: Studienbuch Diakonik, Band 1, ed. Volker Herrmann and Martin Horstmann, Neukirchen-Vluyn: Neukirchener Verlag, 2006, p. 150.

3 Heinz Schmidt, Prägende geschitliche Erfahrungen der Diakonie in Deutschland, in: Fritz Lienhard and Heinz Schmidt, Das Geschank der Solidarität. Chancen und Herausforderungen der Diakonie in Frankreich und Deutschland, Heidelberg: Universitätsverlag Winter, 2006, pp. 70-72.

4 Cf., for example, Gerhard K. Schäfer and Volker Hermann, Geschichtliche Entwicklung der Diakonie von der Alten Kirche bis zur Gegenwart im Überblick, pp. 155-165. 
subsequent legal adoption of Diaconia by the church were correct steps in a good direction. ${ }^{5} \mathrm{He}$ is referring to the Order of Diaconic Work, one of the set of ecclesial orders and constitutions, which incorporates Diaconia into the church structure, attempts to integrate congregational and institutional diakonia, and creates tools for their mutual cooperation. However, with respect to the reality, speaking of an organic incorporation of Diaconia into the body of the church would still be somewhat overstated. ${ }^{6}$

\section{Religion and diakonia in modern society}

As I have shown, the modern development of diakonia manifests both a tendency to a greater autonomy of diakonia and the church and the efforts at their re-connection. Of course, the problem of their relationship is closely related to the general situation of religion in modern society.

The reformers could, with a more or less clear conscience, delegate diaconic responsibility to the structures of secular power, because they were living in an - as yet - not very differentiated Christian society, in which the religious and secular spheres coincided to a large extent. While the conflict between Bucer and the Strasbourg municipal council can be perceived as a manifestation of a competency conflict between the church and the secular government (a kind of 'diaconic investiture' controversy), in modern society there exists a much more fundamental tension arising from functional differentiation. The process is described in detail by Niklas Luhmann as part of his social systems theory. ${ }^{7}$ Besides religion, other separate social systems arise within society, such as politics, healthcare, law or education. These systems are governed by their own binary codes (in the case of religion, for example, transcendence / immanence) and have different functions. According to Dierk Baecker, contemporary society makes it even possible to speak about a separate system of social help, based on the decision to help or not to help. ${ }^{8}$ Of course, this places diakonia, which in this perspective participates in both the system of religion and the system of social help, in a complicated situation.

Pointedly formulated, is it possible to speak of an ecclesial dimension of diakonia when the particular work is done - at least in the secularised areas of Bohemia - mostly by people without a personal bond to the church for public money and according to standards determined by the state? Can diakonia be made ecclesial by the fact that it is performed by an organisation operated by the church, or by hanging bulletin boards with biblical quotations and crosses on the walls in its facilities? And moving to the sphere of pastoral care, is not attention to spiritual needs and an offer of spiritual activities (in the better cases) standard also in secular facilities (chaplains in hospitals, local church services in homes for the elderly, etc.)?

The present state of diakonia can be described in the context of secularisation theory, which determined the main line of thinking up to the second half of the $20^{\text {th }}$ century but has come under serious challenge today. It seems that 'de-religionisation' is not a necessary component of modernity and that its concomitant phenomena are territorially limited more or less to Western Europe. Moreover, even in our cultural sphere it is possible to observe gradual manifestations of the de-privatisation of religion and, as Grace Davie observes, an increase in interest in 'postmaterialistic values' in connection with how society progresses in the second phase of

\footnotetext{
Report of Diaconia of the Evangelical Church of Czech Brethren for 1999, Archive of Diaconia of ECCB. See Karel Šimr, Církevní, nebo světská diakonie?, in: Caritas et veritas 2/2016, pp. 284-298.

More in Karel ŠIMR, Diakonie v perspektivě teorie sociálních systémů, in: Studia theologica 1/2016, pp. 81-95.

Dirk BAECKer, Soziale Hilfe als Funktionssystem der Gesellschaft, in: Zeitschrift für Soziologie 2/1994, pp. 93-110.
} 
modernisation from an industrial economy to an economy based on services, associated with an emphasis on the quality of life. ${ }^{9}$

Luhmann, whose approach I am trying to utilise in the theory of diakonia, in his last work devoted to the sociology of religion (The Religion of Society posthumously published in 2000), regards the concept of secularisation as problematic and questionable. In his view, it is possible to say that religion has become de-institutionalised (i.e., in our context especially 'de-churchified'), but not that it has lost social relevance. He therefore proposes to describe the phenomena, which we have become accustomed to summarily designate as secularisation, more precisely by means of functional differentiation. ${ }^{10}$ According to Luhmann, religion is in a state of structural incompatibilities with the modern functionally differentiated society and is searching for new possibilities of connection. This new situation brings along possibilities and limitations. ${ }^{11}$ The advantages include the fact that being excluded from the system of religion does not imply - as it did in the Middle Ages - being excluded from other social systems and vice versa. The greater autonomy of the religious system is therefore an 'evolutionary advantage' and gives the possibility of inclusion to those who have 'dropped out' of other social systems. ${ }^{12}$ And that is a great challenge especially for diakonia.

So, what is, according to Luhmann, characteristic for the situation of Christianity in Western functionally differentiated society? It is subjected to observation by other social subsystems with different modes of discernment. Luhmann asks 'how the religious system reacts when it is constantly obliged to answer questions it has not raised. ${ }^{13}$ And he asks that evidently through organisation: 'Issues of faith become issues of decision-making. ${ }^{14}$ Since the late Middle Ages it has been possible to observe a process in which the ecclesial structure is gaining importance. To this corresponds the growing emphasis on ecclesiology in theological reflection. But this accent on the church institution as the 'strong tower' of Christianity in the world reinforces the tendency of excluding the church from society. Joachim Matthes, for example, discusses a pointed thesis of the church's emigration from society. ${ }^{15}$ Not only is the society 'de-churchified', the church is also 'de-socialised', which means that 'in its internal composition it no longer represents the forms and structures of society. ${ }^{16}$ And while secularisation can, together with Luhmann, be seen positively as the liberation of Christianity from various secondary social functions to concentrate on its own task, i.e., communicating the gospel, its negative consequence is a certain churchification of Christianity - its concentration upon itself in the form of the church. As a result, tension arises between the church, which is drawing away from society, and diakonia, which is essentially headed towards it. At the same time, it holds that precisely for the in-itself-enclosed modern Western Christianity, diakonia in the public sphere presents a unique challenge to search for its new representation and promotion in society.

9 Grace Davie, Vyjímečný př́pad Evropa: podoby víry v dnešním světě, Brno: CDK, 2009, pp. 184-185.

10 Niklas Luhmann, Die Religion der Gesellschaft, Frankfurt am Main: Suhrkamp, 2000, p. 126.

11 Ibid., pp. 317-318.

12 Ibid., pp. 304-305.

13 Niklas Luhmann, Gesellschaftsstruktur und Semantik, Band 3, Frankfurt am Main: Suhrkamp, 1989, p. 264.

14 Ibid.

15 Joachim Matthes, Die Emigration der Kirche aus der Gesellschaft, Hamburg: Furche-Verlag, 1964.

16 Ibid., p. 14. 


\section{Diakonia as an intersection of Christianity and social help}

I have already mentioned Bárta's words concerning the adoption of diakonia by the church. In debate in the Czech Protestant milieu, the image of diakonia as a daughter of the church is commonly employed - as a child whom the church has birthed, of which it likes to boast, sometimes also reprimands it because it is ungratefully turning away, or respects it as an already adult daughter who is living her own life and maintains more or less a courteous relationship with her mother. But the question arises whether this image of the relationship of mother and daughter reflects the reality of organised diaconic work in modern society, and whether it can be relevantly described within the theory of the constitutive marks of the church, which understands diakonia merely as a form of the self-realisation of the church. As we have seen, in the modern period diakonia in fact arose outside the church, also as a result of the excessive churchification of Christianity. Contemporary real diaconic work participates in the system of social help and is therefore not influenced only by its religious grounding, but must at the same time make provision for the codes of the other relevant social systems - not only social work, but, for example, also of the economy, the law and politics.

In the 1970s, Luhmann distinguished three system references within Christianity: the church, diakonia and theology. The church as a system of spiritual communication performs religion's own function in society, diakonia represents the relationship to the other sub-systems of society and characteristically solves 'residual problems' which 'are created by other systems but cannot be treated by them. ${ }^{17}$ And theology has the task of reflecting upon the church and diakonia. This model also corresponds with the biblical meaning of the concept of diakonia, which - as John N. Collins has emphasised - underscores primarily not a humble service, but a service representing someone, an intermediary service. So diakonia essentially exists 'between worlds'. It constitutes a bridge between the church as a primarily liturgical congregation and those who are outside of it for various reasons. It represents Christianity in the public sphere. It makes participation in Christ's victory over evil possible even for those who cannot participate in liturgically celebrating it in the given community..$^{18}$ I therefore propose to represent the place of diakonia in modern society with a diagrammatical representation by means of two partially overlapping circles, one of which represents the system of social help and the other the system of Christianity, diakonia being the intersection.

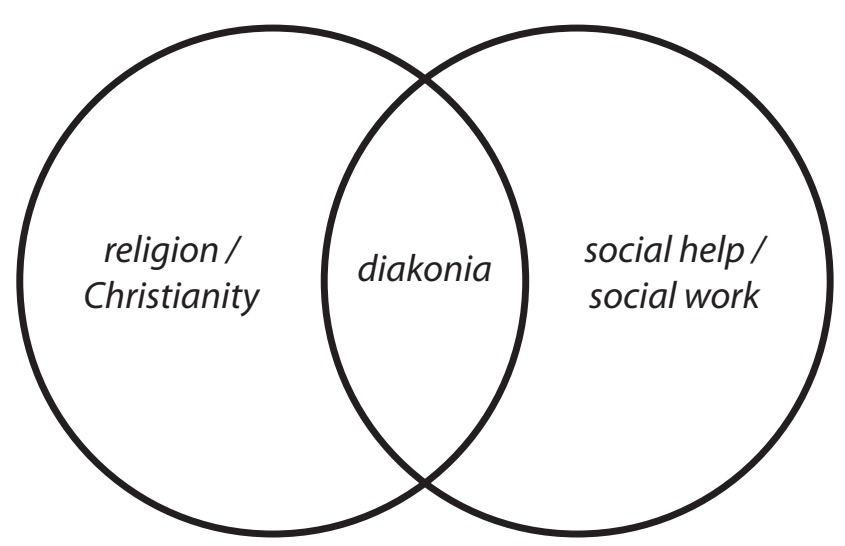

A diagrammatic representation of diakonia as an intersection of the systems of religion and social help

17 Niklas Luhmann, Funktion der Religion, Frankfurt am Main: Suhrkamp Verlag, 1977, p. 58.

18 For more, see Karel ŠIMR, Diakonie v perspektivě teorie sociálních systémů, p. 83. 


\section{Conclusion: diakonia as a sister of the church}

With respect to the historical development, to the present situation of diakonia within the system of public services and to its theological reflection, it seems more appropriate to speak with Beate Hofmann about the modern adoption of diakonia as a foster sister of the church, ${ }^{19}$ the church's fellow traveller in the system of Christianity, its 'sister in Christ.' The loosening of the bond between the church and institutionalised diakonia can lead to - and frequently actually leads to - reflecting upon the diaconic character and responsibility of the ecclesial communities themselves. Of course, we have also seen that the differentiation of the church and diakonia is also accompanied by an effort for their deeper interconnection. So, to grasp the contemporary situation of diakonia it is not sufficient to merely apply the secularisation thesis. In the sphere of social activities, the impact of post-secularism and de-privatisation of religion can also be felt. The functional differentiation of social systems does not contradict the possibility of their structural re-connection with an awareness of the inner differentiation and belonging to different systems. The proposed model of diakonia as an intersection of the social systems of Christianity and social help means that Christian oriented charitable work must involve the simultaneous activation of the codes immanence / transcendence and help / not help and thus places considerable demands on those who take part in the practice. Of course, the connection of social help and Christianity in the form of spiritual communication or the theological reflection of issues of helping in the contemporary world is a very interesting form of the presence of Christianity in society. This connection is not applied merely in performing pastoral activities or in developing theological perspective within interdisciplinary reflection, but also in searching for Christian-adequate forms of managing diaconic facilities or developing the diaconic spirituality of the workers.

The reality of diakonia in the sense indicated above is a remarkable 'hybrid', which by its dual loyalty understandably irritates both the church and society. In diaconic work, incongruent hermeneutics meet on a daily basis, which can be beneficial for both sides: for Christianity it is a bridge to a secularised society estranged from the church and for social work it is an opportunity to search for sources for its basic values, such as, for example, human dignity, so that they do not become worthless.

19 Beate HOFMANN, Ekklesiologische Begründungsansätze von Diakonie, in: Helfendes Handeln im Spannungsfeld theologischer Begrundungsansätze, eds. Heinz RüEgGER and Christoph Sigrist, Zurich: Theologischer Verlag, 2014, p. 98. 


\title{
Diakonia in the Public Sphere - a Daughter of the Church, or its Sister? \\ Church and Diakonia Between Separation and Approximation
}

\begin{abstract}
The paper attempts to localise the contemporary developed forms of organised diaconic activities with respect to church and society. Based on historical, sociological and theological analysis of Christian helping action with respect to its development in the modern period, it articulates the view that the theory of constitutive marks of the church, which conceives diakonia as one of the realising characteristics of the church, is not sufficient for reflecting institutionalised diakonia and charity in modern functionally differentiated society, and it is more appropriate to describe it as a connection of the systems of religion (Christianity) and social help (social work) - and thus to understand it not as a daughter, but as a sister of the church. On the one hand, this brings along the need for a complex interdisciplinary approach to reflect this remarkable 'hybrid', but on the other hand it also requires that helping action in the Christian perspective does not give up its religious qualification, which is to be manifested, for example, in developing the Christian culture of diaconic facilities or in the diaconic spirituality of their workers.
\end{abstract}

Keywords: diakonia, church, social help, social systems theory

\section{Author contact}

\section{Karel Šimr, MA}

University of South Bohemia in České Budějovice

Faculty of Theology, Department of Philosophy and Religious Studies

Kněžská 8, 37001 České Budějovice

simrk@centrum.cz 